NBER WORKING PAPER SERIES

DID RAILROADS MAKE ANTEBELLUM U.S. BANKS MORE SOUND?

\author{
Jeremy Atack \\ Matthew S. Jaremski \\ Peter L. Rousseau \\ Working Paper 20032 \\ http://www.nber.org/papers/w20032
NATIONAL BUREAU OF ECONOMIC RESEARCH
1050 Massachusetts Avenue
Cambridge, MA 02138 \\ April 2014
}

We thank William Collins, Robert Margo, Paul Rhode, David Wheelock and participants in the "Enterprising America" NBER-Vanderbilt University conference, December 14, 2013. The views expressed herein are those of the authors and do not necessarily reflect the views of the National Bureau of Economic Research.

NBER working papers are circulated for discussion and comment purposes. They have not been peerreviewed or been subject to the review by the NBER Board of Directors that accompanies official NBER publications.

(C) 2014 by Jeremy Atack, Matthew S. Jaremski, and Peter L. Rousseau. All rights reserved. Short sections of text, not to exceed two paragraphs, may be quoted without explicit permission provided that full credit, including (C) notice, is given to the source. 
Did Railroads Make Antebellum U.S. Banks More Sound?

Jeremy Atack, Matthew S. Jaremski, and Peter L. Rousseau

NBER Working Paper No. 20032

April 2014

JEL No. N21,N71

\begin{abstract}
$\underline{\text { ABSTRACT }}$
We investigate the relationships of bank failures and balance sheet conditions with measures of proximity to different forms of transportation in the United States over the period from 1830-1860. A series of hazard models and bank-level regressions indicate a systematic relationship between proximity to railroads (but not to other means of transportation) and "good" banking outcomes. Although railroads improved economic conditions along their routes, we offer evidence of another channel. Specifically, railroads facilitated better information flows about banks that led to modifications in bank asset composition consistent with reductions in the incidence of moral hazard.
\end{abstract}

Jeremy Atack

Department of Economics

Vanderbilt University

VU Station B \#351819

2301 Vanderbilt Place

Nashville, TN 37235-1819

and NBER

jeremy.atack@vanderbilt.edu

Matthew S. Jaremski

Colgate University

Department of Economics

13 Oak Drive

Hamilton, NY 13346

and NBER

mjaremski@colgate.edu
Peter L. Rousseau

Professor of Economics

Vanderbilt University

Box 1819, Station B

Nashville, TN 37235

and NBER

peter.1.rousseau@vanderbilt.edu 


\title{
DID RAILROADS MAKE ANTEBELLUM U.S. BANKS MORE SOUND?*
}

\author{
Jeremy Atack \\ Matthew S. Jaremski \\ Peter L. Rousseau
}

\section{Introduction}

Before the Civil War and the passage of the National Banking Acts, banks in the United States were governed by state laws. These laws varied across states and over time, but for the most part shared the common characteristic that bank note issues, where permitted, were not statutorily limited. Prior to the Bank War that ended the federally-chartered Second Bank of the United States in 1836, however, the Second Bank could and did indirectly limit money creation by individual banks through its policy of returning notes to the cashiers of banks for redemption in gold and silver coins. This policy alone was insufficient to ensure universally sound banking practices and the condition of banks and bank money only worsened after the Second Bank's demise. Indeed, the term "wildcat banking" is often used to describe the operation of some U.S. banks during the period that followed until the passage of the National Banking Acts in 1863 and 1864 reformed and reshaped the system. The very idea of wildcat banking is premised on the notion that such banks would tend to locate away from population centers - "where the wildcats throve" ((Quinn and Samad 1991) quoting from Luckett (1980)) - so they could issue notes that would circulate in more populated areas yet be difficult to redeem because of the issuing bank's

\footnotetext{
*We thank William Collins, Robert Margo, Paul Rhode, David Wheelock and participants in the "Enterprising America” NBER-Vanderbilt University conference, December 14, 2013
} 
remoteness. By the time such notes might appear for redemption at the bank of issue, so the legend goes, the wildcat bankers themselves had disappeared.

While there are colorful stories of such instances in antebellum banking history, accounts of this form of wildcatting are surely overstated (Rockoff 1974; Rolnick and Weber 1983). Nevertheless, the American frontier was still quite vast throughout the antebellum period, and it is in this sense that many (or most) banks outside of the eastern cities and a few population centers elsewhere could be considered remote. They might thus have been tempted to take advantage of their remoteness to act in ways that compromised the positions of their liability holders. Even so, this type of "quasi-wildcatting" (for want of a better term) would have suffered a serious setback as improved means of transportation and communications, especially the railroads, diffused through the nation's interior, connecting communities - and their banks -with providing better trading opportunities and faster means of communication that allowed for more direct oversight. Railroads therefore would have made it increasingly difficult for bankers to seek private gain through excessive risk taking as their economic potential improved. In this chapter, we offer evidence that is consistent with and supportive of this hypothesis.

In the decades before the Civil War, the United States economy was transformed from an outpost of the European Atlantic economy perched on the eastern seaboard to a rapidly growing, dynamic domestic economy and continental power. Improvements in transportation were a critical factor in this transformation, and made it possible for large segments of the population to live at ever-increasing distances from natural waterways. Improvements in finance over the period also provided a means of payment that promoted increasingly impersonal trade. To the extent that the railroads drew new banks closer to the centers of economic activity and allowed existing banks to participate in the growth opportunities afforded by efficient connections to 
major population centers, railroads provided incentives for banks to serve their communities while pursuing private profits. It is this sense that railroads may also have helped to align the interests of bankers with their liability holders, providing bankers with a reason to acquiesce to monitoring and to persist as ongoing businesses rather than settle for one-time gains.

The links between transportation improvements and banking were, in some cases, quite explicit and direct. The Illinois legislature, for example, passed "an act to increase the capital stock of certain banks, and to provide means to pay the interest on a loan authorized by an act entitled 'an act to establish and maintain a general system of internal improvements"' (1837; quoted in Callender 1902). ${ }^{1}$ However, as we will show, the positive interaction between transportation improvements and banking was more general and pervasive even where state legislatures did not intervene directly. Specifically, in this chapter we examine the relationship between internal improvements, particularly the railroad, and the survival rates and operating characteristics of banks.

How could railroads have affected the operation of banks? Hitherto, answers to this question have been limited to the suggestion that proximity to transportation routes limited bank opportunities to engage in irresponsible and private rent-seeking (see, for example, Bullock 1900; Dwyer 1996; Economopoulos 1988). We, on the other hand, show in a series of probability models that proximity to a railroad was associated with lower failure rates and better balance sheet management. Moreover, these findings are more wide-reaching than the few documented cases of traditional "wildcatting."

Others have shown that the coming of the railroad was associated with a wide variety of changes associated with economic growth and development. These range from increases in

\footnotetext{
${ }^{1}$ Indiana and Tennessee also passed similar laws.
} 
urbanization, higher farm land values, and greater agricultural productivity to the growth of large scale manufacturing plants and more investment in education (Atack et al. 2010; Atack, Haines, and Margo 2011; Atack and Margo 2011; Atack, Margo, and Perlman 2012). Each of these changes separately and collectively should have increased the attractiveness of an area to banks. Moreover, elsewhere, we have shown that nearly half of new Midwest banks established after 1840 opened within a few years of a railroad's arrival in their county (Atack, Jaremski, and Rousseau 2013).

Here, we describe a mechanism by which railroads not only affected finance on the extensive margin, but also led to efficiency changes that enhanced the intensity of financial intermediation. And, of course, it is the interaction of the intensity of intermediation along with its quantity that seems most important for long-run growth (Rousseau and Wachtel 1998, 2011). This relationship proves to be one that does not generalize to all types of transportation; rather, railroads seem to have been the only transportation methods that affected banks in this way.

Our chapter is organized as follows. In Section 2 we offer some background on the nature of antebellum banking. Section 3 describes our data. These make extensive use of geographic information systems (GIS) technology for transportation and bank locations. Section 4 contains estimates from a series of multivariate proportional hazard models that relate proximity to transportation with lower bank failure rates and more sound balance sheet characteristics. Section 5 concludes.

\section{Antebellum Bank Failures}

The key to understanding the operation of antebellum banks is to recognize their reliance on bank notes rather than deposits as the dominant means of financing their operations. Unlike 
today, deposits during the period were not demandable or subject to check writing, nor were they a high priority debt. Therefore, to obtain liquidity and make investments, states gave banks the right to issue bank notes. These notes functioned as a medium of exchange in the marketplace but they were also dollar-denominated liabilities that promised to pay the equivalent in specie when demanded by the noteholder at the bank of issue. They thus also served as a store of value. Due to the importance of bank notes in the payments system, states generally mandated that each note be fully backed by some form of collateral. Moreover, the state representative could close and liquidate the bank to redeem all outstanding notes if so much as a single request for note redemption went unmet.

Prior to 1837 , each potential bank petitioned its state legislature for a unique charter and approval thereof depended as much on political influence as on need. ${ }^{2}$ The terms of these charters varied according to the whims of particular legislatures, but most states allowed almost any asset to be used as collateral for a bank's notes and even allowed the bank itself to hold the collateral on site. ${ }^{3}$ But beginning in 1837 and gaining momentum in the early 1850 s, a series of "free banking" laws in some states replaced the need for legislative approval of each individual bank with general enabling legislation that established instead a well-defined set of capital, reserve, and note requirements. ${ }^{4}$ While reserve requirements and the like still varied by state, the

\footnotetext{
${ }^{2}$ For convenience, we define "charter banks" to be any institution established by direct order of a state legislature. This distinction is necessary because charter banks continued to operate even after free bank laws were passed.

${ }^{3}$ Most banks notes described the type of assets used as collateral somewhere on the note.

${ }^{4}$ Three states adopted free banking in the late 1830s. One other, Alabama, would do so in the (very late) 1840s. Eleven states, however, passed free banking laws between 1850 and 1853 with two others (Iowa and Minnesota) passing laws in 1858. See Rockoff (1975) and Rolnick and Weber (1983).
} 
new laws generally mandated that free banks purchase specific types of assets, often that state's (or federal) debt as collateral for each note. ${ }^{5}$ Moreover, this collateral was to be held by the state in trust and only relinquished when the bank returned an equal amount in notes.

Despite this backing requirement, the assets of closed banks were not always sufficient to cover their note circulations due to adverse market fluctuations in the price of the collateral assets. In such cases, bank notes were redeemed at cents on the dollar, as would be the usual case in bankruptcy actions. Rockoff (1974) and Rolnick and Weber (1983) show that some of the losses were minimal (most Indiana banks, for example, redeemed at 95 cents on the dollar), but in other cases losses were nearly total (e.g., Minnesota "railroad" banks repaid less than 35 cents of each dollar issued).

Following Rolnick and Weber (1984), we consider "failed banks" to be those institutions which did not redeem their notes at full value. "Closed banks," on the other hand, simply ceased operations but repaid their notes at par. Based on this distinction, 30 percent of the 861 free banks that ever existed ended in failed. In comparison, only 19 percent of the 1,828 charter banks failed, even though charter banks could back their notes with almost any type of asset.

Based on an examination of bank balance sheets over time, Jaremski (2013) reached two conclusions about free bank failures. First, the highly-specific backing requirements for note issues mandated in the various free banking laws seem to be the underlying cause of the free banking system's high failure rate relative to the charter banking system. Moreover, this statistical relationship was not the result of general declines in bond prices. Rather, banks were sensitive only to the prices of those bonds used as collateral. Second, solvent free banks seem to have diversified their assets away from bonds (to loans, for example) and their liabilities away

\footnotetext{
${ }^{5}$ Other assets were occasionally allowed to back notes, such as real estate in Michigan and slaves in Georgia.
} 
from note circulation (to equity or debt), and these actions seem to have at least partially shielded those banks from bond price declines.

From both theoretical and empirical standpoints, however, other factors might also play an important role in the success or failure of financial intermediaries, especially factors related to the community and the environs that these banks served. Here, we examine the effects of transportation and communications improvements on bank operations and survival. Such an analysis was hitherto nearly impossible due to a lack of comprehensive data on bank locations relative to means of transportation and communication, yet recent advances in the development of historical geographic information systems databases have now removed this impediment.

As Table 1 shows, the distance of a bank from the nearest railroad was positively correlated with the probability of bank failure for both charter and free banks - that is to say, the further away that a bank was from a railroad, the more likely the bank would fail. Only $7.2 \%$ of charter banks within 10 miles of a railroad failed compared to $34.5 \%$ of those located further away. ${ }^{6}$ Failure rates among free banks are higher but show the same pattern. Whereas $15.8 \%$ of free banks within 10 miles of a railroad failed, the rate among those located at a greater distance was $60.2 \%$. Plausible variations in the distance cut-off show the same pattern: banks located closer to railroads were less likely to fail than those located further away. This pattern is consistent with a central role for market forces in bank survival.

Canals, however, did not have the same stabilizing effect across either bank type. The probability of failure is roughly the same for charter banks on and off a canal, whereas free banks

\footnotetext{
${ }^{6}$ This is not to imply that those banks at a greater distance that failed should be considered "wildcat banks." Our choice of 10 miles is arbitrary but represents a distance that someone might plausibly cover on foot to tend to important business and which could easily and routinely be covered on horseback.
} 
on a canal were more than 20 percentage points less likely to fail. One possible explanation for the difference in pattern between charter and free banks with respect to canal proximity is that free banks only began to be chartered after 1837, by which time most canals had already been built or were under construction, thereby removing some of the uncertainties about local development prospects and progress.

There are several possible explanations for why proximity to a railroad might have affected the probability of bank failure for both free and charter banks. First, railroads brought population and increased economic activity to an area (Atack et al. 2010; Atack, Haines, and Margo 2011). These additions would have increased a bank's access to liquidity and increased its return on loans. Moreover, since railroads often encouraged the development of larger scale manufacturing, they might have allowed banks to diversify their loan portfolios more fully and lower their exposure to agricultural shocks. Indeed, Bodenhorn (2003) shows that banks often held loan portfolios matching the distribution of firms in the surrounding area.

Second, the arrival of a railroad would have increased the acceptability of bank notes by enabling noteholders to reach the bank more quickly and cheaply while simultaneously increasing local demand for the means of payment as trade and commerce expanded. Notes from trusted banks would be discounted less and also travel further from the bank, but noteholders and exchange centers in large cities could more easily return notes en masse if they thought the bank was operating riskily. Indeed, Gorton (1999) and Jaremski (2011) show that the discount from face value at which a bank's note traded at in New York City and Philadelphia was tied to the transportation costs of returning the note as well as the bank's riskiness, whereas Bodenhorn (1998) shows that bank discounts increased several quarters before banks actually failed, 
suggesting that bank specific information was an important determinant of note values. ${ }^{7}$

Therefore, a railroad's arrival may have encouraged banks to hold less risky portfolios and adjust their operations to reflect the new degree of community and noteholder oversight as it took advantage of the increased acceptability of their notes.

Third, locations with a railroad might have simply attracted more stable bankers. Certainly, statements by contemporaries suggested that "wildcat banks" tended to form in wilderness areas where they could issue notes that they never intended to redeem. While such accounts surely overstate the case, banks that wanted to take greater risks and avoid firsthand oversight by regulators should have been less likely to locate along a transportation route.

As suggested by Table 1, however, the benefits of railroads would not necessarily have translated to all forms of transportation. Access to the coastline would have expanded an area's ability to trade, but most of that trade tended to be centered in major ports (e.g., New York City, Boston, and New Orleans, or Detroit and Buffalo on the Great Lakes). Rivers and canals were more geographically specific, but they were slow and indirect, making them better suited to transporting bulky, heavy goods rather than passengers and time sensitive goods (including financial instruments). Moreover, other than the Erie Canal, most canals did not have much longterm financial success and were quickly displaced by railroads. Consequently, canals would not have had the same effect on a location's urbanization and manufacturing activities as the railroad, and certainly would not have enabled quick redemption of bank notes or increased the opportunity for bank supervision and oversight.

\footnotetext{
${ }^{7}$ While Gorton uses distance between cities, Jaremski calculated the specific travel cost using travel guides that provided the specific cost of each railroad trip in 1836, 1851, 1856, and 1861.
} 


\section{Data}

We restrict our analysis to those areas of the country that were a part of the United States from 1840 onwards, ${ }^{8}$ and to those parts of the United States for which it is possible to get consistent geographic boundaries that map into political units since we also use various census county data as controls in our estimations. ${ }^{9}$ The county level information are from the Haines (2010) update of the original ICPSR (1979) decennial census county database.

Using two antebellum bank databases originally assembled by Warren Weber (Weber 2008; Weber 2005), we construct a dataset that provides financial and biographical information for almost every bank in operation in the United States between 1830 and 1862. Weber's data end in 1860, but Jaremski (2010) extends the bank census to the outbreak of the Civil War using annual editions of the Merchants and Bankers' Almanac (Merchant and Bankers' Almanac s.d.). These provide comprehensive lists of U.S. banks in each year. This extension is important for two reasons. First, over 120 banks failed in 1861 and 1862, and excluding these failures halves the failure rate of free banks, thereby making them appear much more stable than they were.

\footnotetext{
${ }^{8}$ Thus, for example, Texas which was not annexed by the United States until 1845 and California which was ceded to the U.S. by Mexico in 1848 are excluded from the analysis.

${ }^{9}$ This restriction excludes much of Iowa and the northern part of Wisconsin and all points north and west thereof but retains all of Arkansas, Louisiana, and Missouri. Our procedure differs from the "border fix" solution proposed by Hornbeck (2010) who essentially redistributes population and economic production proportionately among counties based upon their loss or gain of territory from adjacent counties. Instead, we adopt the GIS-based procedure used by Atack, Jaremski, and Rousseau (2013) but broadened to encompass the entire settled area of the United States by combining non-GIS identical counties within a state into contiguous areas made up of variable numbers of individual counties in each year sharing a common external boundary.

We limited this linkage procedure to the period from 1840 onwards because extending it back to 1830 would necessitate the combination of nearly all Midwest and Southern counties into "super-counties." Moreover, since the few banks existing in 1830 and 1835 were almost solely in Northeast counties that did not change borders, it was more efficient to exclude those few counties that changed boundaries in this period and then pick them back up in 1840. Our results are similar if we eliminate observations from 1830 and 1835 or if we do not include census variables but include all banks.
} 
Second, because our empirics examine the failure of banks in subsequent years, we would either have to assume implicitly that all banks in operation in 1860 survived (when they did not), or end our analysis before then. Either choice would bias the findings. In the process of extending Weber's databases, we have also taken the opportunity to make a few other changes based upon the directory listings and other contemporaneous information. ${ }^{10}$

The augmented database contains information on 2,689 banks of which 2,582 were located within the geographic bounds for which we can define consistent political borders. Of these, 156 banks were excluded from our analysis since they closed their doors before 1830 . Furthermore, we excluded banks with missing data, particularly balance sheet data. ${ }^{11}$ The final bank database contains information on 1,818 banks. Collectively, these exclusions slightly bias our sample towards more stable (possibly non-fraudulent) banks.

The transportation data come from a number of different GIS databases including three covering transportation for the antebellum period that have been developed by Atack (2013) from a variety of contemporary and retrospective sources. These include historic digitized maps, modern topographical maps produced by the U.S. Geological Survey showing "old railroad grade" and other features of the landscape (like the remains of a canal bed or a lock), reports by various government agencies, compilations from travel guides, and the like. The databases provide information on the location and operational dates for canals, steamboats on rivers, and railroads.

\footnotetext{
${ }^{10}$ The changes involved merging banks that "closed" in one year with those that "opened" almost immediately thereafter under the same name. We believe that these reflect charter renewals or mergers so that the "new" bank was not necessarily an entering bank. We also dropped those banks with undefined start and end dates.

${ }^{11}$ We also excluded, for example, banks which were opened and closed within one of the quinquennia intervals that are our basic interval of analysis as described below.
} 
The canal mapping was initially derived from those produced by Poor (1970) and by Goodrich (1961) for 1860 but modified with respect to exact locations based upon USGS topographical maps and histories of the various canals. ${ }^{12}$ These histories also provide a dating as to when specific sections of each canal were first opened (and closed) to traffic. For rivers, we defined navigability in terms of the river's use by steamboats, ignoring earlier as well as concomitant use of the waterway by other craft such as rafts, canoes, and bateaux because only steamboats provided speedy and reliable service both upstream as well as down (Haites, Mak, and Walton 1975; Hunter 1949). The dating and details of which communities were served by steamboats is based upon sources such as Hunter (1949), contemporary gazetteers (Rowell Geo. P. \& Co. 1873), newspaper accounts, and reports by the U.S. Army Corp of Engineers who eventually assumed responsibility for maintaining and promoting navigation of the nation's rivers (U. S. Congress. House. et al. 1871). We also generated coastlines for the Great Lakes, the Atlantic and the Gulf of Mexico from the NHGIS shapefiles. ${ }^{13}$

Whereas the river and canal GIS databases provide annual information on the extent of navigation, our railroad databases only provide snapshots at 5-year intervals because of the difficulty of assembling a reliable annual series from the sources we have consulted. ${ }^{14}$ The

\footnotetext{
${ }^{12}$ See especially Whitford's (1906) history of the Erie Canal. Briefer discussions of other canals have been produced by various historical societies. For example, http://www.indcanal.org/ regarding canals in Indiana and http://www.middlesexcanal.org/ or http://www.winchestermass.org/canal.html on the Middlesex Canal.
}

${ }^{13}$ This proved more complicated than the simple description suggests because of the extremely high resolution of the TIGER files that underlie the NHGIS shapefiles and the complexity of coastal features that include bays, headlands, inlets and estuaries as well as small islands.

${ }^{14}$ Unfortunately, the most obvious source from which to produce a mapping — maps — cannot be used to produce an accurate annual mapping because of uncertainty regarding dating (copyright $\mathrm{v}$. titling v. underlying data) and imprecision arising from factors such as the map scale, imperfect surveying, and care with which the engraving was made. The work of Paxson (1914) 
railroad GIS files also differ from those for water transportation in so far as they are (currently) less precisely located. Today, we can map exact locations using satellite imagery and GPS. Historically, however, the railroad network was much more extensive than that which we have today but much of the old roadbed has been recycled and reused (for example, by highways), obscuring its earlier use. For example, according to Historical Statistics, miles of main railroad track essentially plateaus between 1916 and 1930 at around 260,000 but had declined to under 183,000 miles by 1980 (a decline of about 30\%) and there are substantially fewer miles today (Carter et al. 2006, Series Df932). Track has also been realigned and straightened due to improvements in civil engineering and the advent of higher speed trains on some routes, thereby changing the historical railroad route.

Atack's mappings of historical railroads are, instead, based on small scale, state-level maps of the rail system in 1911 by Matthews Northrup Co. for the "New Century Atlas" (Whitney and Smith 1911). Where railroad lines are still in operation today or appear on USGS topographical maps, these 1911 maps have proved to be very accurately and carefully drawn, especially taking into account the limitations created by their small scale. These maps were georeferenced against NHGIS state boundary shapefiles using the ArcGIS 10 software, and the rail lines shown were then traced into their own shapefiles. These shapefiles thus define the location and extent of railroads in 1911. Mappings for earlier years were created by working backwards in time, based upon what Atack thought to be the "best" mapping of the rail system in a particular year and then deleting lines from the later shapefile that did not appear on the earlier

for the five midwestern states of the Old Northwest before the Civil War, however, shows that such a goal may ultimately be attainable given sufficient time to cull through literary sources such as the American Railroad Journal (1832), annual reports of various railroads and the American Railway Guide (see, for example,Cobb 1945; 1850). 
map. ${ }^{15}$ For our purposes, the map for year $t$ is based upon the map for year $(t+5)$ working backwards from Atack's (2013) 1860 mapping of the rail system, generated by the procedure described above. ${ }^{16}$

Using these various GIS and geocoded databases, we are able to measure the distance between each bank and its nearest railroad, canal, steam navigable river, ocean, and Great Lake every five years starting in $1830 .^{17}$

Our analysis includes a number of controls. In particular, we add a bond price index to control for the value of a bank's collateral against notes from Jaremski (2010). For each bank, this index is the average fraction of par value for those bonds eligible as note collateral. While most states allowed any state or federal bonds paying full interest to be used in this way, someAlabama, New Jersey, New York, and Ohio_-only allowed their banks to use specific bonds. The bond price index in states not subject to a specific bond constraint consists of the average for the 14 available state bonds. However, per state law, the index for Alabama and New Jersey banks contains only the U.S. Treasury bonds, while Ohio banks were limited to holding only Ohio state bonds. ${ }^{18}$ The situation in New York was more complex. Prior to the 1842 change in its

\footnotetext{
15 The specific maps underlying each shapefile are generally those drawn by the most respected mapmakers of the time including Colton and Rand McNally both of whom published topical and frequently updated travel guides. See reader guides from the Library of Congress $(1984 ; 1975)$

${ }^{16}$ The "base" map for the 1860 mapping (subject to the procedures detailed in the text) was by J. H. Colton (Colton 1860).

${ }^{17}$ Distances are measured by ArcGIS using the Toolbox function, "Near" from the Analysis/Proximity toolbox for use in our panel. These are "as the crow flies" distances and the GIS mappings are projected in Albers equal area.

${ }^{18}$ States that did not pass a free banking law are assumed to face no bond constraint.
} 
free banking law, the index for New York banks is the average of the 14 state bonds as for most other states but the index thereafter contains only New York state bonds.

Figure 1 shows the decennial coevolution of banks and railroads between 1830 and 1860 . It also shows the geographical bounds of our analysis. In 1830, banks tended to be concentrated in the Northeast and along the eastern seaboard. The few railroads then in existence were generally short, such as the Baltimore and Ohio which had 14 miles of track stretching towards Washington DC or the Tuscumbia Railway Company in Alabama which operated 2 miles of track reaching to the Tennessee River. ${ }^{19}$ Consequently, in 1830 , relatively few banks -33 by our count-were "on a railroad," that is, operated within 10 miles of one. This is fewer than 10 percent of all banks (Table 2). During the ensuing decades, banks — and railroads—spread into the Midwest, but spread much more slowly in the South, especially during the 1850s. During the 1830s, however, the railroad system expanded rapidly primarily east of the Appalachians. Consequently, by 1840, the fraction of banks within 10 miles of a railroad had grown sevenfold to almost two-thirds of all banks. By 1850 , more than 80 percent of banks were within a 10 miles of a railroad.

There was also a marked increase in the percentage of banks within 10 miles of a canal as Pennsylvania and New York built out their state canal systems and Ohio began to follow suit. As a result, the fraction of banks located close to canals peaked around 1850. For navigable rivers, the peak was in 1840 and a majority of banks never was located in close proximity to either canals or navigable rivers. However, the geographic association between banks and other modes of transportation was much weaker than it was for railroads despite antebellum improvements in these means of transportation. Moreover, the declining fraction of banks located within 10 miles

${ }^{19}$ See, for example, the database (and related notes) for 1830 at http://oldrailhistory.com. 
of the coast (and changes with respect to proximity to the Great Lakes) reflect shifts in the locus of economic activity and population as U.S. economic development pushed westwards.

\section{Empirical Analysis}

The empirical analysis uses the multivariate proportional-hazard model with time varying covariates proposed by Cox (1972; Cox and Oakes 1984), and models the probability of failure of bank $i$ given survival to the period $t$ as:

$$
\lambda\left(t, X_{i}, \beta, \lambda_{0}\right)=\lim _{h \rightarrow 0} \frac{P(t \leq T<t+h \mid T \geq t)}{h}=\lambda_{0} \exp \left(X_{i}(t) \beta\right)
$$

where $T$ is the failure date, $\lambda_{0}$ is the baseline hazard function common to all banks, and the exponential function captures the effects of the explanatory variables, $X_{i}$. Cox's method estimates the equation using a semi-parametric "partial likelihood" approach that requires the specification of the scale function but not the baseline hazard. Moreover, and of particular relevance for our use here, the model takes account of a bank's specific entry and exit dates even though we might only observe the bank at a few specific moments, identifying the $\beta$ s from variation across starting and failure dates. ${ }^{20}$ Because our railroad data are only observed at 5-year intervals, each observation covers a 5-year period and the $\beta$ coefficients should be interpreted as effects of the variables on the probability of failure over the following 5 years.

Like a panel probit or logit model, the hazard function treats each period that a bank was open $(t)$ as a unique observation linked to the individual bank (hence the 5,636 observations although our dataset contains only 1,818 individual banks for which we have all the necessary

\footnotetext{
${ }^{20}$ The model treats banks which were solvent at the end of 1862 or which closed during the period as censored observations.
} 
information). However, it gains efficiency over other binary choice models by explicitly taking into account survival through that period. The hazard model also explicitly accounts for bank age. Therefore, even if we do not observe a bank early in its operation, the hazard model does not mistakenly consider it as a new bank.

On the other hand, a drawback of the model is the need to make additional assumptions regarding the initial hazard function in order to calculate the marginal effect of each variable. Absent good information, we are reluctant to make assumptions regarding those initial conditions, and instead report the raw coefficients. These provide information on the direction and relative size of an explanatory variable's effect on the probability of failure but not on its marginal effect.

We measure the impact of transportation using a series of dummy variables that indicate whether a particular transportation method (i.e., railroad, canal, ocean, river, or Great Lakes coastline) was within 10 miles of the bank, which we think of as close enough to enter a user's choice set. We will show later that the results are not sensitive to reasonable variations in this distance.

Our choice of other explanatory variables is motivated by modern bank regulatory practice that was implemented in 1979 under the Uniform Financial Institutions Rating System (Federal Deposit Insurance Corporation 1997) and the information available on each bank from 19th century balance sheets. In particular, we lack information on a bank's income or the quality of its assets and management, and thus are unable to estimate the full set of CAMELS measures that 
modern regulators use to assess a bank's soundness. Instead, we follow Jaremski (2010) and construct as many CAMELS metrics as possible. ${ }^{21}$ Specifically,

- The average value of the state's allowable fraction of par or market value on bonds used as collateral measures the bank's "S

- $\log ($ Assets $)$ measures size differences among banks but is not a metric that modern regulators consider in their CAMELS rating;

- Capital (defined as the ratio of Capital to Total Assets) measures "Capital adequacy";

- Specie (defined as Specie divided by Total Assets) is an index of bank "Liquidity", measuring the bank's capacity to meet bank runs in specie;

- Deposits (defined as the ratio of Deposits to Total Assets) measure the bank's liability diversity;

- Loans (defined as the ratio of Loans and Discounts to Total Assets) and Bonds (defined as the ratio of state and U.S. government assets on the bank's balance sheet to Total Assets) measure asset diversity and quality; ${ }^{22}$

- Circulation (defined as the ratio of Circulation to Total Assets) measures the level of potential future redemptions.

Moreover, we include fixed effects for states to account for heterogeneity across them such as regulatory enforcement and for individual years to account for the periodic financial panics and specie suspensions during the period from 1830 to $1860 .^{23}$

${ }^{21}$ The CAMELS ratings are a modern measure of a bank's quality. Each letter stands for a factor

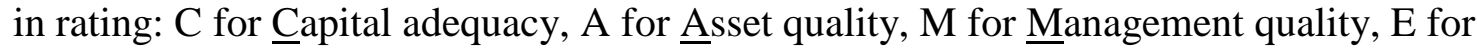

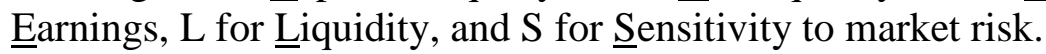

${ }^{22}$ Unlike modern studies where government debt is generally considered safe, Loans can also be thought of as a crude measure of "Assset quality" due to their relatively high return and short maturity compared to bonds of the period. 


\subsection{The Effects of Proximity to Railroads on Bank Failure Rates}

The first column in Table 3 presents estimates of Equation (1) with only the transportation variables, a dummy variable for free $b a n k s^{24}$, year fixed effects, and state fixed effects. The second column then adds bank balance sheet variables and the average bond price to the specification. As access to transportation could have altered the composition of a bank's balance sheet, the first column provides the full effect of transportation on bank stability, whereas to measure the full effect of transportation in the second column we must include something about how balance sheets changed in response to transportation.

The results show a tendency for free banks to be less stable than chartered banks over the five-year intervals we examine. However, once we control for balance sheet variables, the positive coefficient loses its statistical significance and even becomes negative.

Railroads are the only transportation type that has a negative impact on bank failure. ${ }^{25}$

Moreover, that effect is statistically significant. While the coefficients do not represent marginal effects, the underlying hazard ratios indicate the effect of having a railroad nearby was quite large. This effect becomes smaller when we add balance sheet variables to the specification but remains statistically and economically significant, suggesting that railroads may have pushed

${ }^{23}$ Given the small number of banks in most counties, county-fixed effects would degrade the model into a bank-fixed effect and limit us from comparing stable banks that did not fail to those that did.

${ }^{24}$ When we estimate the hazard functions separately for free and charter banks, the railroad coefficient is significantly negative for free banks and insignificantly negative for charter banks. The insignificance for charter banks, however, seems to be the result of banks that entered after a railroad. Once these late entering charter banks are dropped, the coefficient regains its significance and grows in magnitude.

${ }^{25}$ The results for railroads are similar when we include banks outside the consistent and constant 1840 boundaries. The only change is that the coefficient on the Great Lakes dummy is not then statistically significant. 
bankers to reduce the riskiness of their portfolios. Alternatively, banks that were close to rivers and the Great Lakes actually seem more likely to fail. The fact that the other transportation methods do not stabilize banks indicates that railroads were special. Not only did they bring greater economic diversity and population to the area, but they also would have enabled sudden note redemption and greater noteholder oversight.

Several of the other variables also have a statistically significant effect on bank failure. The value of bond collateral is negatively and significantly related to the probability of failure. While the size of the coefficient is based on the large declines in bond prices during the early parts of the Civil War, the coefficient remains significant for other periods due to the declines in bonds just prior to the Panics of 1837, 1839, and 1857. Larger banks with more reserves, loans, and deposits and fewer bank notes were less likely to fail. These results are consistent with Jaremski (2010) despite our inclusion of the transportation variables.

While railroads seem associated with bank stability, this raises the obvious question of how they might have affected bank operations. The most obvious answer is that the railroads brought about greater urbanization (Atack et al. 2010) and other changes associated with economic development thus generating more banks deposits and greater scrutiny. To capture this, we add the log of population and the fraction of population living in an urban area to the hazard model to the final two columns of Table $3 .{ }^{26}$ While the additions slightly reduce the railroad coefficient, it remains both statistically and economically significant. To the extent that

\footnotetext{
${ }^{26}$ We implicitly assume that population and urbanization grew at constant rates between successive decennial censuses. While we would like to include measures of manufacturing and agriculture, these are not included in the Census until after 1830. See Wright (1900).
} 
railroads were exogenous to existing bank stability, they made banks less likely to fail through changes in balance sheet variables and urbanization as well as through other channels. ${ }^{27}$

While urbanization tends to reduce the probability of bank failure, this factor is not statistically significant when we include the balance sheet variables - probably because the size of the bank was in part dependent on the size of its customer base. While the inclusion of the census variables lowers the effect of railroads, it actually increases the effect of being on a navigable river and on the Atlantic Coast. The lower positive coefficients on these variables when we do not control for urbanization thus might be due to the tendency for most urban areas before 1830 to be located along water routes, and especially those close to the coast. Once the stabilizing effect of urbanization is removed, water transportation is associated with a higher probability of bank failure.

\subsection{Controls for Potential Endogeneity of Railroad Entry}

To interpret the coefficient on railroads as causal, the timing and the location of the railroad must be exogenous, and there are reasons why the route chosen by railroads (especially in the Northeast) would not have been related to the stability of banking. ${ }^{28}$ While we cannot fully

\footnotetext{
${ }^{27}$ Some banks were clearly endogenous to internal improvements such as railroads. For example, the 1837 Illinois law "to increase the capital stock of certain banks, and to provide means to pay the interest on a loan authorized by an act entitled 'an act to establish and maintain a general system of internal improvements" (1837; quoted in Callender 1902). Even more directly, some banks and railroads were chartered jointly, such as the Erie and Kalamazoo Railroad Bank and the Benton and Manchester Railroad and Banking Co. in Mississippi. To the extent that bank officers held wealth and influence in the local community, it is likely that they also acted as "boosters." As such, they would have been actively solicited as investors in any railroad promotion. We discuss these and other endogeneity issues in Sec. 4.2.

${ }^{28}$ We have also estimated two stage least squares models using the number of miles that a bank was away from the nearest straight line linking the nation's 15 largest cities as an instrument. As railroads were costly to build, a straight line between cities was the most likely ex ante path regardless of banks. In the 2 SLS models, the coefficient on the railroad dummy loses its
} 
control for this type of endogeneity, we can control for two other possible sources. First, railroads were attracted to populated areas and sources of economic activity because these generated people and cargo to carry. This economic opportunity also attracted banks. Many of these attractions are captured by the other transportation media and by the county population variables, but other economically meaningful metrics such as production data are not available before 1840 for the entire country. ${ }^{29}$

In Table 4, we truncate the earlier years of our sample period so that we can control for manufacturing capital (1840-1860) and agricultural capital per person (1850-1860). This approach not only captures the endogeneity of railroads but also captures the effect of railroads on economic activity. Even when we include these variables, the coefficient on the railroad variable remains negative and statistically significant. This is consistent with railroads affecting banks through note redemptions, population, economic activity, and possibly other factors. It also should be noted that the stabilizing effect of railroads seems to grow over time as the coefficient is larger for the 1840 s and 1850 s than for the longer period. This is likely due to the spread of banks and rails into the undeveloped Midwest and the emergence of a more interconnected and extensive transportation system.

Second, it is possible that only stable banks entered an area after the arrival of railroad transportation because only relatively conservative, conventional banks could survive in the

statistical significance but remains negative. When banks that entered after a railroad are dropped from the sample, the 2SLS estimate for the railroad dummy becomes more negative and statistically significant. Consequently, we believe the results are not driven by endogeneity of existing stable banks and might be slightly biased downward banks that followed railroads (a result that is confirmed in Table 5).

${ }^{29}$ There was a census of manufactures in 1820 but virtually nothing is recorded for the Midwest or South despite the fact that we know there were flour milling everywhere and quite sophisticated machine shops and foundries in Cincinnati and Louisville. Moreover, the county level tabulations are seriously flawed (See United States. Census Office. 1990). 
more transparent, connected environment associated with the railroad. The results in the previous tables thus could partially reflect this reverse causation because the railroad forced structural changes in the way that existing banks operated. However, this type of behavior does not detract from our story. In fact, it might even be the more important aspect of railroads' effects on bank survival and performance given the charges of wildcat banking. To check on this, we examine whether railroads had the same effect on existing banks as on new entrants. In Table 5, we present two additional types of specifications: (1) eliminating observations for banks that entered after a railroad was in operation in the local area, and (2) removing banks that were present before and after a railroad came within 10 miles. In all cases, the coefficient on the railroad dummy is negative and significant, showing that railroads seem to have stabilized both existing banks and new banks. Comparing the two sets of coefficients, the largest (and seemingly more consistent) effect seems to come from banks that were present before a railroad entered — that is to say we believe that banks changed their behavior when the railroad came close.

\subsection{Sensitivity to Different Mileage Cutoffs}

Thus far we have treated "close to a railroad" as being within 10 ("as the crow flies") miles of a railroad. Our choice of cutoff reflects our view that this was a reasonable distance that contemporaries routinely covered by horseback or wagon. It can also be traversed on foot albeit with more effort. Our results, however, are not particularly sensitive to reasonable and plausible variations in this cutoff. Specifically, we have re-estimated the model specifications including the balance sheet variables from Table 3 for even mileage cutoffs between 4 and 20 miles. The

resulting coefficients and standard error bands for the railroad dummy both with and without the county variables are shown in Figure 2. This shows that banks within 14 miles of a railroad, absent county controls, are significantly less likely to fail. Such a distance is at the limit of a 
day's (laden) wagon ride and generally beyond what one might consider walking except in unusual circumstances. Accounting for county-to-county differences narrows the band to between 6 and 10 miles of a railroad. Outside of these ranges, railroads have no statistically significant effect on bank failure. Moreover, it is worth noting the coefficient on the railroad dummy variable was largest for a cutoff of 6 miles, meaning our use of a 10-mile cutoff slightly biases the results towards zero.

\subsection{The Effects of Proximity to Railroads on Bank Balance Sheets}

The introduction of the balance sheet variables into the model consistently reduces the size of the railroad coefficient. We take this to suggest that banks altered the composition of their assets in response to proximity of the railroad and this made them financially stronger and less likely to fail. We test this possible explanation using the following model:

$$
Y_{i, t}=a+\beta_{1} \operatorname{Ln}(\text { Age })_{i, t}+\beta_{2} \text { Free }_{i, t}+\beta_{3} X_{i, t}+t_{t}+u_{i}+e_{i, t}
$$

where the dependent variable $Y_{i, t}$ represents the several balance sheet variables discussed above, $\operatorname{Ln}(\text { Age })_{i, t}$ is the logarithm of a bank's age, Free $e_{i, t}$ is a free bank dummy, $t_{t}$ is a time fixed effect, and $u_{i}$ is either a bank fixed or a state fixed effect. Depending on which fixed effects are included, the translation of the railroad coefficient changes. When the fixed effects are not included, the coefficient would at least be partially identified relative to other banks, whereas when it is included, it will only be identified relative to the bank's own time series.

It is important to note that this analysis also provides insight into how railroads were affecting banks. As previously argued, population growth along the rails might have increased the liquid funds a bank would have access to, manufacturing growth might have increased the profitability of loans, or the threat of sudden note redemption might have pushed banks to 
decrease their circulations. Therefore, by seeing which aspects of a bank's balance sheet change, we can gain some understanding of how railroads influenced bank behavior.

The results in Table 6 show that the arrival of a railroad made for larger banks relative to other banks. This is consistent with the findings of others regarding the economic impact of railroads on urbanization and various kinds of economic activity (Atack et al. 2010; Atack, Haines, and Margo 2011; Callender 1902). The railroad dummy coefficient is only statistically significant for assets when not including bank-fixed effects.

When looking at the balance sheet ratios, banks decreased the amount of their excess reserves and made more loans after the arrival of a railroad, possibly because more profitable opportunities now existed for these potentially loanable assets. These are the only two variables for which the railroad coefficient is statistically significant in both columns. On the other hand, a bank seems to have decreased its circulation and bond holdings relative to surrounding banks and decreased its deposits after the arrival of a railroad. ${ }^{30}$ Decreased note circulation is consistent with a presumed increase in the ease and likelihood that notes would be presented for payment when the railroad made travel easier and faster. The overall pattern of results indicates that one of the key effects of railroads on banks was through the increased economic impact rather than through population or increased monitoring.

Putting these results in the context of bank failure, railroads seem to lowered failure rates by encouraging banks to operate more safely through increased loan as well as lowered bond holdings and circulations, yet also relate to lower holdings of reserves. The latter could simply reflect a greater sense of confidence in banks among the public when located near a railroad, and

\footnotetext{
${ }^{30}$ The combined decline in deposits and circulation suggests that either profit or interbank deposits rose after a railroad entered as these were the remaining two large liability items.
} 
this allowed them to reduce primary and secondary reserves because of the repeat trades in which they engaged. ${ }^{31}$

\section{Conclusion}

The decades before the Civil War witnessed the transformation of the United States economy into a rapidly growing, dynamic domestic economy and continental power. The nation's bourgeoning financial system was one of the factors at the heart of this transformation (Rousseau and Sylla 2005). However, it was not a smooth development. The financial system was subject to periodic panics and crises, and as a result, nearly a third of all banks created before 1862 closed with their noteholders sustaining losses. Some important changes taking place contemporaneously in the economy may have mitigated these losses. By linking detailed bank and transportation data, we show that the arrival of railroads may have helped stabilize the system despite the association of financial crises with investment cycles and the speculative internal improvements that came with them.

The data indicate the railroads were positively correlated with bank stability even after controlling for local economic activity and population, whereas other means of transportation were either uncorrelated or negatively correlated with bank stability. The effect is apparent not only for banks existing before the railroads went through, but also for new banks that opened up after the rails. Moreover, the arrival of a railroad seems to have encouraged banks to hold safer portfolios consisting of fewer bonds and banknotes and more loans. These changes would well have driven local investment in the local economy, which implies that railroads could have had important indirect effects on local economic growth through the longevity of banks and the

31 This seems reasonable given that findings of Gorton (1999) and Jaremski (2011) as banks that could be more quickly reached had lower bank note discounts. 
stability of longer-term finance. These effects reach beyond the traditional arguments about agglomeration of economic activity usually associated with the arrival of the railroad. 


\section{Bibliography}

An Act to increase the capital stock of certain banks...establish and maintain a general system of internal improvements. Tenth General Assembly, March 4, 1837.

American Railroad Journal. 1832. American railroad journal, and advocate of internal improvements. New York: s.n.

Atack, Jeremy. 2013. "On the Use of Geographic Information Systems in Economic History: The American Transportation Revolution Revisited." Journal of Economic History no. 73 (2):313-38.

Atack, Jeremy; Fred Bateman; Michael Haines, and Robert A Margo. 2010. "Did Railroads Induce or Follow Economic Growth? Urbanization and Population Growth in the American Midwest, 1850-1860." Social Science History no. 34 (2):171-97.

Atack, Jeremy; Michael Haines, and Robert A Margo. 2011. "Railroads and the Rise of the Factory: Evidence for the United States, 1850-1870." In Economic Evolution and Revolutions in Historical Time, edited by Paul Rhode, Joshua Rosenbloom and David Weiman. Palo Alto: Stanford University Press.

Atack, Jeremy; Matthew Jaremski, and Peter L. Rousseau. 2013. American Banking and the Transportation Revolution Before the Civil War. Nashville TN and Hamilton, NY: Vanderbilt University and Colgate University.

Atack, Jeremy; Robert A Margo, and Elizabeth Perlman. 2012. The impact of railroads on school enrollment in nineteenth century America. Boston: Boston University.

Atack, Jeremy and Robert A. Margo. 2011. "The Impact of Access to Rail Transportation on Agricultural Improvement: The American Midwest as a Test Case, 1850-1860." Journal of Transportation and Land Use no. 4 (2).

Bodenhorn, Howard. 1998. "Quis Custodiet Ipsos Custodes." Eastern Economic Journal no. 24 (1):7-24.

Bodenhorn, Howard. 2003. State banking in early America : a new economic history. New York: Oxford University Press.

Bullock, Charles Jesse. 1900. Essays on the monetary history of the United States, The citizen's library of economics, politics, and sociology. New York, London,: Macmillan and Co.

Callender, G. S. 1902. "The Early Transportation and Banking Enterprises of the States in Relation to the Growth of Corporations." The Quarterly Journal of Economics no. 17 (1):111-162.

Carter, Susan B.; Scott Sigmund Gartner; Michael R. Haines; Alan L. Olmstead; Richard Sutch; Gavin Wright, and Louis P. Cain. 2006. Historical Statistics of the United States Millennial Edition Online. New York: Cambridge University Press.

Cobb, Charles. 1945. American railway guide and pocket companion for the United States: containing correct tables for time of starting from all stations, distances, fares, etc. on all the railway lines in the United States : together with a complete railway map : also many principal steamboat and stage lines running in connection with railroads. Milwaukee, Wis.: Kalmbach Pub. Co.

Colton, J. H. 1860. Colton's new railroad \& county map of the United States and the Canadas \&c. New York: Joseph Hutchins Colton.

Cox, D. R. 1972. "Regression Models and Life-Tables." Journal of the Royal Statistical Society. Series B (Methodological) no. 34 (2):187-220. doi: 10.2307/2985181. 
Cox, D. R. and David Oakes. 1984. Analysis of survival data, Monographs on statistics and applied probability. London; New York: Chapman and Hall.

Dinsmore, Curran. 1850. "American railway guide, and pocket companion for the United States ... together with a complete railway map." In. S.1.: C. Dinsmore,. http://proxy.library.umkc.edu/login?url=http://infotrac.galegroup.com/itweb/univmomille $\mathrm{r} ? \mathrm{db}=\mathrm{SABN}$.

Dwyer, Gerald. 1996. "Wildcat Banking, Banking Panics and Free Banking in the United States." Federal Reserve Bank of Atlanta Economic Review no. 81:1-20.

Economopoulos, Andrew J. 1988. "Illinois Free Banking Experience." Journal of Money, Credit and Banking no. 20 (2):249-264.

Federal Deposit Insurance Corporation, . FDIC Law, Regulations, Related Acts. 62 Fed. Reg. 752, January 6, 1997, effective January 1, 1997, September 16, 20131997 [cited 11/25/2013. Available from http://www.fdic.gov/regulations/laws/rules/5000-900.html.

Goodrich, Carter, ed. 1961. Canals and American economic development. New York,: Columbia University Press.

Haines, Michael R and Inter-university Consortium for Political and Social Research. 2010. Historical, Demographic, Economic, and Social Data: The United States, 1790-2002: Inter-university Consortium for Political and Social Research (ICPSR) [distributor].

Haites, Erik F.; James Mak, and Gary M. Walton. 1975. Western river transportation : the era of early internal development, 1810-1860, The Johns Hopkins University studies in historical and political science. Baltimore: The Johns Hopkins University Press.

Hornbeck, Richard. 2010. "Barbed Wire: Property Rights and Agricultural Development." Quarterly Journal of Economics no. 125 (2):767-810.

Hunter, Louis C. 1949. Steamboats on the Western rivers; an economic and technological history, Studies in economic history. Cambridge,: Harvard University Press.

Inter-university Consortium for Political and Social Research. 1979. Historical, Demographic, Economic, And Social Data: The United States, 1790-1970.

Jaremski, Matthew. 2010. "Free Bank Failures: Risky Bonds versus Undiversified Portfolios." Journal of Money, Credit and Banking no. 42 (8):1565-1587. doi: 10.1111/j.15384616.2010.00354.x.

Jaremski, Matthew. 2013. "State Banks and the National Banking Acts: Measuring the Response to Increased Financial Regulation, 1860-1870." Journal of Money, Credit and Banking no. 45 (2-3):379-399. doi: 10.1111/jmcb.12006.

Library of Congress. and Andrew M. Modelski. 1984. Railroad maps of North America : the first hundred years. Washington: Library of Congress : For sale by the Supt. of Docs., U.S. G.P.O.,.

Library of Congress. Geography and Map Division. and Andrew M. Modelski. 1975. Railroad maps of the United States : a selective annotated bibliography of original 19th-century maps in the Geography and Map Division of the Library of Congress. Washington: The Library : for sale by the Supt. of Docs., U.S. Govt. Print. Off.

Luckett, Dudley G. 1980. Money and banking. 2d ed. New York: McGraw-Hill.

Merchant and Bankers' Almanac. s.d. The Merchants and Bankers' almanac. New York: J. S. Homans.

Paxson, Frederic L. 1914. "The Railroads of the "Old Northwest" before the Civil Wat." Transactions of the Wisconsin Academy of Sciences, Arts, and Letters no. 17 (Part 1):247-274. 
Poor, Henry Varnum. 1970. History of the railroads and canals of the United States of America, Library of early American business \& industry, 34. New York,: A. M. Kelley.

Quinn, Stephen F and A Samad. 1991. "Wildcat Banking in Illinois: A Look into Our Financial History." Illinois Business Review no. 48 (4):16-17.

Rockoff, Hugh. 1974. "The Free Banking Era: A Reexamination." Journal of Money, Credit, and Banking no. 6:141-67.

Rockoff, Hugh. 1975. The free banking era : a re-examination, Dissertations in American economic history. New York: Arno Press.

Rolnick, Arthur J. and Warren Weber. 1984. "The Causes of Free Bank Failures: A Detailed Examination." Journal of Monetary Economics no. 14:269-91.

Rolnick, Arthur J. and Warren E. Weber. 1983. "New Evidence on the Free Banking Era." The American Economic Review no. 73 (5):1080-1091.

Rousseau, Peter L. and Richard Sylla. 2005. "Emerging Financial Markets and Early U.S. Growth." Explorations in Economic History no. 42 (1):1-26.

Rousseau, Peter L. and Paul Wachtel. 1998. "Financial Intermediation and Economic Performance: Historical Evidence from Five Industrialized Countries." Journal of Money, Credit, and Banking no. 30:657-78.

Rousseau, Peter L. and Paul Wachtel. 2011. "What is Happening to the Impact of Financial Deepening on Economic Growth." Economic Inquiry no. 49 (1):276-88.

Rowell Geo. P. \& Co. 1873. Geo. P. Rowell \& co's gazetteer, containing a statement of the industries, characteristics, population and location of all towns in the United States and British America, in which newspapers are published. New York,: G.P. Rowell \& co.

U. S. Congress. House.; U. S. Army. Corps of Engineers; U. S. War Department, and U. S. War Department. Engineer Department. 1871. Engineer's report of certain rivers and harbors. Letter from the Secretary of War, transmitting reports of the Chief Engineer upon the improvement of certain rivers and harbors. February 21, 1871.

United States. Census Office. 1990. Digest of accounts of manufacturing establishments in the United States and of their manufactures : made under direction of the Secretary of State, in pursuance of a resolution of Congress, of 30th March, 1822. Edited by Publishing Norman Ross, Norman Ross Publishing series ; v. 6. New York, N.Y.: Norman Ross Publ.

Weber, Warren. 2008. Balance sheets for U.S. Antebellum State Banks. edited by Minneapolis Federal Reserve.

Weber, Warren E. 2005. Census of State Banks. edited by Minneapolis Federal Reserve Bank. Whitford, Noble E. 1906. History of the Canal System of the State of New York, Together with Brief Histories of the Canals of the United States and Canada. Supplement to the Annual Report of the Engineer and Surveyor of the State of New York. Vol. Two. Albany: Brandow Printing Co.

Whitney, William Dwight and Benjamin E. Smith. 1911. The Century dictionary and cyclopedia, with a new atlas of the world. Rev. and enl. ed. 12 vols. New York,: The Century co.

Wright, Carroll D. 1900. History and Growth of the United States Census. Washington DC: GPO. 
Table 1: Proximity to Transportation and Bank Outcomes

\begin{tabular}{lccc}
\hline Charter Banks & Number of Banks & \% Fail & \% Close \\
On Rail & 1014 & $7.2 \%$ & $11.0 \%$ \\
Not on Rail & 203 & $34.5 \%$ & $39.9 \%$ \\
& & & \\
On Canal & 517 & $10.7 \%$ & $12.6 \%$ \\
Not on Canal & 700 & $12.6 \%$ & $18.1 \%$ \\
& & & \\
Free Banks & & & \\
On Rail & 493 & $15.8 \%$ & $21.9 \%$ \\
Not on Rail & 108 & $60.2 \%$ & $27.8 \%$ \\
& & & \\
On Canal & 279 & $11.8 \%$ & $25.8 \%$ \\
$\quad$ Not on Canal & 322 & $34.2 \%$ & $20.5 \%$ \\
\hline
\end{tabular}

Notes: Banks are denoted as being on a rail or canal if they were within 10 miles of one at any time between 1830 and 1862 . 
Table 2: The Expanding Transportation Web and Percentage of Banks Located Near Specific Forms of Communication and Transportation

\begin{tabular}{|c|c|c|c|c|c|c|}
\hline Year & $\begin{array}{l}\text { Number } \\
\text { of banks }\end{array}$ & $\begin{array}{c}\% \text { within } 10 \\
\text { miles of a } \\
\text { railroad }\end{array}$ & $\begin{array}{c}\% \text { within } 10 \\
\text { miles of a } \\
\text { canal }\end{array}$ & $\begin{array}{c}\% \text { within } 10 \\
\text { miles of a } \\
\text { navigable } \\
\text { river }\end{array}$ & $\begin{array}{l}\% \text { within } 10 \\
\text { miles of the } \\
\text { Great Lakes }\end{array}$ & $\begin{array}{l}\% \text { within } 10 \\
\text { miles of the } \\
\text { coast }\end{array}$ \\
\hline 1830 & 343 & 9.6 & 34.1 & 31.2 & 1.7 & 58.9 \\
\hline 1835 & 557 & 38.6 & 45.4 & 35.2 & 2.9 & 53.0 \\
\hline 1840 & 711 & 62.3 & 47.7 & 36.1 & 5.2 & 47.1 \\
\hline 1845 & 611 & 71.4 & 48.9 & 31.3 & 5.2 & 47.8 \\
\hline 1850 & 738 & 82.2 & 49.7 & 29.3 & 6.4 & 43.5 \\
\hline 1855 & 1226 & 88.1 & 47.1 & 32.0 & 6.5 & 38.1 \\
\hline 1860 & 1353 & 91.4 & 44.3 & 33.3 & 5.5 & 36.7 \\
\hline
\end{tabular}

Note: Percentages in any year add to more than 100 because a bank could be in close proximity to two or more different modes of transportation. 
Table 3: Determinants of Bank Failure (1830-1860)

\begin{tabular}{|c|c|c|c|c|}
\hline Free Bank Dummy & $\begin{array}{l}0.729 * * \\
{[0.295]}\end{array}$ & $\begin{array}{c}-0.148 \\
{[0.339]}\end{array}$ & $\begin{array}{c}0.662 * * \\
{[0.295]}\end{array}$ & $\begin{array}{c}-0.158 \\
{[0.340]}\end{array}$ \\
\hline Within 10 Miles of Railroad & $\begin{array}{c}-0.598^{* * *} \\
{[0.130]}\end{array}$ & $\begin{array}{c}-0.279 * * \\
{[0.128]}\end{array}$ & $\begin{array}{c}-0.354 * * * \\
{[0.137]}\end{array}$ & $\begin{array}{l}-0.227^{*} \\
{[0.137]}\end{array}$ \\
\hline Within 10 Miles of Canal & $\begin{array}{c}0.050 \\
{[0.155]}\end{array}$ & $\begin{array}{c}0.187 \\
{[0.155]}\end{array}$ & $\begin{array}{l}0.287 * \\
{[0.160]}\end{array}$ & $\begin{array}{c}0.243 \\
{[0.160]}\end{array}$ \\
\hline Within 10 Miles of River & $\begin{array}{c}0.057 \\
{[0.130]}\end{array}$ & $\begin{array}{l}0.246^{*} \\
{[0.128]}\end{array}$ & $\begin{array}{c}0.22 \\
{[0.135]}\end{array}$ & $\begin{array}{l}0.289 * * \\
{[0.128]}\end{array}$ \\
\hline Within 10 Miles of Great Lakes & $\begin{array}{c}0.198 \\
{[0.245]}\end{array}$ & $\begin{array}{c}0.614 * * * \\
{[0.217]}\end{array}$ & $\begin{array}{c}0.535^{* *} \\
{[0.244]}\end{array}$ & $\begin{array}{c}0.731 * * * \\
{[0.224]}\end{array}$ \\
\hline Within 10 Miles of Atlantic Coast & $\begin{array}{c}-0.221 \\
{[0.228]}\end{array}$ & $\begin{array}{c}0.234 \\
{[0.246]}\end{array}$ & $\begin{array}{c}0.231 \\
{[0.277]}\end{array}$ & $\begin{array}{c}0.337 \\
{[0.261]}\end{array}$ \\
\hline Ln(Population) & & & $\begin{array}{c}-0.039 \\
{[0.068]}\end{array}$ & $\begin{array}{c}0.047 \\
{[0.072]}\end{array}$ \\
\hline Fraction Urban & & & $\begin{array}{c}-1.673 * * * \\
{[0.460]}\end{array}$ & $\begin{array}{l}-0.629 \\
{[0.465]}\end{array}$ \\
\hline Bond Value & & $\begin{array}{c}-0.022 * * * \\
{[0.008]}\end{array}$ & & $\begin{array}{c}-0.021 * * * \\
{[0.008]}\end{array}$ \\
\hline Bonds/Assets & & $\begin{array}{c}-0.398 \\
{[0.657]}\end{array}$ & & $\begin{array}{c}-0.281 \\
{[0.667]}\end{array}$ \\
\hline Circulation/Assets & & $\begin{array}{c}2.704 * * * \\
{[0.872]}\end{array}$ & & $\begin{array}{c}2.517 * * * \\
{[0.888]}\end{array}$ \\
\hline $\ln$ (Assets) & & $\begin{array}{c}-0.358 * * * \\
{[0.080]}\end{array}$ & & $\begin{array}{c}-0.334 * * * * \\
{[0.082]}\end{array}$ \\
\hline Capital/Assets & & $\begin{array}{l}1.720^{* *} \\
{[0.836]}\end{array}$ & & $\begin{array}{l}1.671^{* *} \\
{[0.831]}\end{array}$ \\
\hline Specie/Assets & & $\begin{array}{c}-10.426 * * * \\
{[2.429]}\end{array}$ & & $\begin{array}{c}-10.144 * * * \\
{[2.472]}\end{array}$ \\
\hline Loans/Assets & & $\begin{array}{c}-1.038^{* *} \\
{[0.436]}\end{array}$ & & $\begin{array}{c}-1.081 * * \\
{[0.438]}\end{array}$ \\
\hline Deposits/Assets & & $\begin{array}{c}-2.705^{* *} \\
{[1.242]}\end{array}$ & & $\begin{array}{c}-2.704 * * \\
{[1.245]}\end{array}$ \\
\hline Observations & 5,539 & 5,539 & 5,539 & 5,539 \\
\hline Pseudo R-squared & 0.140 & 0.178 & 0.145 & 0.178 \\
\hline
\end{tabular}

Notes: The model is a proportional-hazard partial likelihood model. The dependent variable is the whether the bank failed during the following five-year period. The model treats each five-year period a bank was open as a unique observation but links them under the individual bank. Fixed effects for state and each five-year period have been added to all specifications. Robust standard errors are listed below the coefficients in brackets. $*$ denotes significance at $10 \%$; ** at $5 \%$ level and $* * *$ at $1 \%$ level. 
Table 4: Tests of the Effect of Railroads on Bank Failure Including Additional County Controls

\begin{tabular}{|c|c|c|c|c|c|c|c|c|}
\hline \multirow[b]{2}{*}{ Free Bank Dummy } & \multicolumn{4}{|c|}{$1840-1860$} & \multicolumn{4}{|c|}{$1850-1860$} \\
\hline & $\begin{array}{l}0.621 * * \\
{[0.298]}\end{array}$ & $\begin{array}{l}0.529 * \\
{[0.298]}\end{array}$ & $\begin{array}{l}-0.239 \\
{[0.338]}\end{array}$ & $\begin{array}{l}-0.251 \\
{[0.339]}\end{array}$ & $\begin{array}{c}-0.444 \\
{[0.554]}\end{array}$ & $\begin{array}{l}-0.614 \\
{[0.601]}\end{array}$ & $\begin{array}{c}-1.755^{* * *} \\
{[0.650]}\end{array}$ & $\begin{array}{c}-1.826 * * * \\
{[0.669]}\end{array}$ \\
\hline Within 10 Miles of Railroad & $\begin{array}{c}-0.646 * * * \\
{[0.132]}\end{array}$ & $\begin{array}{c}-0.369 * * * \\
{[0.140]}\end{array}$ & $\begin{array}{c}-0.321 * * \\
{[0.130]}\end{array}$ & $\begin{array}{l}-0.268 * \\
{[0.139]}\end{array}$ & $\begin{array}{c}-0.789 * * * \\
{[0.149]}\end{array}$ & $\begin{array}{c}-0.437 * * \\
{[0.180]}\end{array}$ & $\begin{array}{c}-0.390 * * \\
{[0.163]}\end{array}$ & $\begin{array}{c}-0.406 * * \\
{[0.198]}\end{array}$ \\
\hline Within 10 Miles of Canal & $\begin{array}{c}0.029 \\
{[0.158]}\end{array}$ & $\begin{array}{l}0.285^{*} \\
{[0.162]}\end{array}$ & $\begin{array}{c}0.131 \\
{[0.156]}\end{array}$ & $\begin{array}{c}0.187 \\
{[0.161]}\end{array}$ & $\begin{array}{l}-0.262 \\
{[0.235]}\end{array}$ & $\begin{array}{c}0.031 \\
{[0.235]}\end{array}$ & $\begin{array}{l}-0.023 \\
{[0.239]}\end{array}$ & $\begin{array}{c}0.082 \\
{[0.248]}\end{array}$ \\
\hline Within 10 Miles of River & $\begin{array}{c}0.073 \\
{[0.131]}\end{array}$ & $\begin{array}{l}0.232 * \\
{[0.138]}\end{array}$ & $\begin{array}{c}0.282 * * \\
{[0.129]}\end{array}$ & $\begin{array}{c}0.318 * * \\
{[0.131]}\end{array}$ & $\begin{array}{c}0.127 \\
{[0.161]}\end{array}$ & $\begin{array}{l}0.279 * \\
{[0.162]}\end{array}$ & $\begin{array}{c}0.216 \\
{[0.159]}\end{array}$ & $\begin{array}{l}0.300 * \\
{[0.157]}\end{array}$ \\
\hline $\begin{array}{l}\text { Within } 10 \text { Miles of } \\
\text { Great Lakes }\end{array}$ & $\begin{array}{c}0.243 \\
{[0.240]}\end{array}$ & $\begin{array}{c}0.561 * * \\
{[0.239]}\end{array}$ & $\begin{array}{c}0.655 * * * \\
{[0.211]}\end{array}$ & $\begin{array}{c}0.739 * * * \\
{[0.221]}\end{array}$ & $\begin{array}{l}-0.926^{*} \\
{[0.501]}\end{array}$ & $\begin{array}{l}-0.181 \\
{[0.491]}\end{array}$ & $\begin{array}{c}-0.384 \\
{[0.535]}\end{array}$ & $\begin{array}{c}0.130 \\
{[0.534]}\end{array}$ \\
\hline $\begin{array}{l}\text { Within } 10 \text { Miles of } \\
\text { Atlantic Coast }\end{array}$ & $\begin{array}{l}-0.350 \\
{[0.246]}\end{array}$ & $\begin{array}{c}0.050 \\
{[0.301]}\end{array}$ & $\begin{array}{c}0.095 \\
{[0.262]}\end{array}$ & $\begin{array}{c}0.164 \\
{[0.277]}\end{array}$ & $\begin{array}{l}-0.436 \\
{[0.376]}\end{array}$ & $\begin{array}{c}0.097 \\
{[0.444]}\end{array}$ & $\begin{array}{c}0.174 \\
{[0.388]}\end{array}$ & $\begin{array}{c}0.301 \\
{[0.419]}\end{array}$ \\
\hline Ln(Population) & & $\begin{array}{c}-0.009 \\
{[0.069]}\end{array}$ & & $\begin{array}{c}0.063 \\
{[0.075]}\end{array}$ & & $\begin{array}{c}0.036 \\
{[0.087]}\end{array}$ & & $\begin{array}{c}0.126 \\
{[0.097]}\end{array}$ \\
\hline Fraction Urban & & $\begin{array}{c}-1.312 * * \\
{[0.523]}\end{array}$ & & $\begin{array}{c}-0.387 \\
{[0.527]}\end{array}$ & & $\begin{array}{c}-3.034 * * * \\
{[0.721]}\end{array}$ & & $\begin{array}{c}-1.624 * * \\
{[0.673]}\end{array}$ \\
\hline Ln(Mfg. Capital P.C.) & & $\begin{array}{c}-0.225^{* *} \\
{[0.104]}\end{array}$ & & $\begin{array}{c}-0.100 \\
{[0.105]}\end{array}$ & & $\begin{array}{l}-0.010 \\
{[0.115]}\end{array}$ & & $\begin{array}{c}0.146 \\
{[0.122]}\end{array}$ \\
\hline Ln(Farm Capital P.C.) & & & & & & $\begin{array}{l}-0.127 \\
{[0.226]}\end{array}$ & & $\begin{array}{c}0.224 \\
{[0.259]}\end{array}$ \\
\hline Bond Value & & & $\begin{array}{c}-0.030 * * * \\
{[0.008]}\end{array}$ & $\begin{array}{c}-0.030 * * * \\
{[0.008]}\end{array}$ & & & $\begin{array}{c}0.011 \\
{[0.020]}\end{array}$ & $\begin{array}{c}0.011 \\
{[0.020]}\end{array}$ \\
\hline Bonds/Assets & & & $\begin{array}{c}-0.671 \\
{[0.677]}\end{array}$ & $\begin{array}{c}-0.620 \\
{[0.690]}\end{array}$ & & & $\begin{array}{c}-0.196 \\
{[1.065]}\end{array}$ & $\begin{array}{c}0.297 \\
{[1.069]}\end{array}$ \\
\hline Circulation/Assets & & & $\begin{array}{c}3.031 * * * \\
{[0.914]}\end{array}$ & $\begin{array}{c}2.811 * * * \\
{[0.934]}\end{array}$ & & & $\begin{array}{c}2.509 * * \\
{[1.137]}\end{array}$ & $\begin{array}{c}2.286 * * \\
{[1.147]}\end{array}$ \\
\hline $\ln$ (Assets) & & & $\begin{array}{c}-0.358 * * * \\
{[0.080]}\end{array}$ & $\begin{array}{c}-0.337 * * * \\
{[0.082]}\end{array}$ & & & $\begin{array}{c}-0.713^{* * *} \\
{[0.124]}\end{array}$ & $\begin{array}{c}-0.662 * * * \\
{[0.128]}\end{array}$ \\
\hline Capital/Assets & & & $\begin{array}{l}1.839 * * \\
{[0.886]}\end{array}$ & $\begin{array}{c}1.785 * * \\
{[0.880]}\end{array}$ & & & $\begin{array}{c}1.187 \\
{[1.153]}\end{array}$ & $\begin{array}{c}1.169 \\
{[1.169]}\end{array}$ \\
\hline Specie/Assets & & & $\begin{array}{c}-10.099 * * * \\
{[2.505]}\end{array}$ & $\begin{array}{c}-9.736 * * * \\
{[2.551]}\end{array}$ & & & $\begin{array}{c}-15.128 * * * \\
{[4.216]}\end{array}$ & $\begin{array}{c}-14.991 * * * \\
{[4.338]}\end{array}$ \\
\hline Loans/Assets & & & $\begin{array}{c}-1.030 * * \\
{[0.441]}\end{array}$ & $\begin{array}{c}-1.076 * * \\
{[0.442]}\end{array}$ & & & $\begin{array}{c}-0.421 \\
{[0.614]}\end{array}$ & $\begin{array}{c}-0.507 \\
{[0.622]}\end{array}$ \\
\hline Deposits/Assets & & & $\begin{array}{c}-2.894 * * \\
{[1.318]}\end{array}$ & $\begin{array}{c}-2.926 * * \\
{[1.320]}\end{array}$ & & & $\begin{array}{l}-2.345 \\
{[1.489]}\end{array}$ & $\begin{array}{l}-2.326 \\
{[1.513]}\end{array}$ \\
\hline Observations & 4,639 & 4,639 & 4,639 & 4,639 & 3,317 & 3,317 & 3,317 & 3,317 \\
\hline Pseudo R-squared & 0.120 & 0.126 & 0.163 & 0.164 & 0.170 & 0.181 & 0.215 & 0.219 \\
\hline
\end{tabular}

Notes: The model is a proportional-hazard partial likelihood model. The dependent variable is the whether the bank failed during the following five-year period. The model treats each five-year period a bank was open as a unique observation but links them under the individual bank. Fixed effects for state and each five-year period have been added to all specifications. Robust standard errors are listed below the coefficients in brackets. $*$ denotes significance at $10 \%$; ** at $5 \%$ level and $* * *$ at $1 \%$ level. 
Table 5: Additional Tests of the Effect of Railroads on Bank Failure (1830-1860)

\begin{tabular}{|c|c|c|c|c|c|c|c|c|}
\hline \multirow[b]{2}{*}{ Free Bank Dummy } & \multicolumn{4}{|c|}{ Dropping Banks that Entered After Railroad } & \multicolumn{4}{|c|}{$\begin{array}{c}\text { Dropping Banks that Were Present When } \\
\text { Railroads Entered }\end{array}$} \\
\hline & $\begin{array}{c}1.103 * * * \\
{[0.412]}\end{array}$ & $\begin{array}{c}1.121 * * * \\
{[0.412]}\end{array}$ & $\begin{array}{c}0.368 \\
{[0.565]}\end{array}$ & $\begin{array}{c}0.390 \\
{[0.563]}\end{array}$ & $\begin{array}{c}0.872 * * \\
{[0.364]}\end{array}$ & $\begin{array}{c}0.786 * * \\
{[0.369]}\end{array}$ & $\begin{array}{l}-0.381 \\
{[0.364]}\end{array}$ & $\begin{array}{l}-0.421 \\
{[0.368]}\end{array}$ \\
\hline $\begin{array}{l}\text { Within } 10 \text { Miles } \\
\text { of Railroad }\end{array}$ & $\begin{array}{c}-1.258 * * * \\
{[0.293]}\end{array}$ & $\begin{array}{c}-1.131 * * * \\
{[0.302]}\end{array}$ & $\begin{array}{c}-0.868 * * * \\
{[0.280]}\end{array}$ & $\begin{array}{c}-0.881 * * * \\
{[0.300]}\end{array}$ & $\begin{array}{c}-0.805^{* * *} \\
{[0.141]}\end{array}$ & $\begin{array}{c}-0.538 * * * \\
{[0.153]}\end{array}$ & $\begin{array}{c}-0.445^{* * *} \\
{[0.145]}\end{array}$ & $\begin{array}{c}-0.388 * * \\
{[0.157]}\end{array}$ \\
\hline $\begin{array}{l}\text { Within } 10 \text { Miles } \\
\text { of Canal }\end{array}$ & $\begin{array}{c}0.276 \\
{[0.231]}\end{array}$ & $\begin{array}{c}0.314 \\
{[0.231]}\end{array}$ & $\begin{array}{c}0.356 \\
{[0.223]}\end{array}$ & $\begin{array}{c}0.345 \\
{[0.227]}\end{array}$ & $\begin{array}{l}-0.013 \\
{[0.175]}\end{array}$ & $\begin{array}{c}0.197 \\
{[0.174]}\end{array}$ & $\begin{array}{c}0.161 \\
{[0.181]}\end{array}$ & $\begin{array}{c}0.208 \\
{[0.179]}\end{array}$ \\
\hline $\begin{array}{l}\text { Within } 10 \text { Miles } \\
\text { of River }\end{array}$ & $\begin{array}{c}-0.158 \\
{[0.162]}\end{array}$ & $\begin{array}{c}-0.093 \\
{[0.167]}\end{array}$ & $\begin{array}{l}-0.015 \\
{[0.165]}\end{array}$ & $\begin{array}{c}-0.007 \\
{[0.166]}\end{array}$ & $\begin{array}{c}0.014 \\
{[0.139]}\end{array}$ & $\begin{array}{c}0.143 \\
{[0.147]}\end{array}$ & $\begin{array}{c}0.180 \\
{[0.135]}\end{array}$ & $\begin{array}{c}0.223 \\
{[0.137]}\end{array}$ \\
\hline $\begin{array}{l}\text { Within } 10 \text { Miles of } \\
\text { Great Lakes }\end{array}$ & $\begin{array}{c}0.544 \\
{[0.423]}\end{array}$ & $\begin{array}{c}0.578 \\
{[0.437]}\end{array}$ & $\begin{array}{c}0.537 \\
{[0.405]}\end{array}$ & $\begin{array}{c}0.572 \\
{[0.414]}\end{array}$ & $\begin{array}{c}0.136 \\
{[0.241]}\end{array}$ & $\begin{array}{l}0.439 * \\
{[0.249]}\end{array}$ & $\begin{array}{c}0.455 * * \\
{[0.217]}\end{array}$ & $\begin{array}{c}0.586 * * \\
{[0.228]}\end{array}$ \\
\hline $\begin{array}{l}\text { Within } 10 \text { Miles of } \\
\text { Atlantic Coast }\end{array}$ & $\begin{array}{c}-0.114 \\
{[0.357]}\end{array}$ & $\begin{array}{c}0.066 \\
{[0.389]}\end{array}$ & $\begin{array}{c}0.203 \\
{[0.356]}\end{array}$ & $\begin{array}{c}0.230 \\
{[0.370]}\end{array}$ & $\begin{array}{c}-0.340 \\
{[0.291]}\end{array}$ & $\begin{array}{c}0.180 \\
{[0.347]}\end{array}$ & $\begin{array}{c}0.090 \\
{[0.307]}\end{array}$ & $\begin{array}{c}0.242 \\
{[0.327]}\end{array}$ \\
\hline Ln(Population) & & $\begin{array}{c}0.029 \\
{[0.091]}\end{array}$ & & $\begin{array}{c}0.069 \\
{[0.100]}\end{array}$ & & $\begin{array}{l}-0.050 \\
{[0.073]}\end{array}$ & & $\begin{array}{c}0.057 \\
{[0.077]}\end{array}$ \\
\hline Fraction Urban & & $\begin{array}{c}-0.975 \\
{[0.729]}\end{array}$ & & $\begin{array}{c}0.051 \\
{[0.776]}\end{array}$ & & $\begin{array}{c}-1.644 * * * \\
{[0.547]}\end{array}$ & & $\begin{array}{c}-0.718 \\
{[0.518]}\end{array}$ \\
\hline Bond Value & & & $\begin{array}{c}-0.001 \\
{[0.009]}\end{array}$ & $\begin{array}{c}-0.001 \\
{[0.009]}\end{array}$ & & & $\begin{array}{c}-0.034 * * * \\
{[0.009]}\end{array}$ & $\begin{array}{c}-0.033 * * * \\
{[0.009]}\end{array}$ \\
\hline Bonds/Assets & & & $\begin{array}{c}-0.443 \\
{[0.907]}\end{array}$ & $\begin{array}{c}-0.415 \\
{[0.914]}\end{array}$ & & & $\begin{array}{c}-0.556 \\
{[0.683]}\end{array}$ & $\begin{array}{c}-0.394 \\
{[0.696]}\end{array}$ \\
\hline Circulation/Assets & & & $\begin{array}{c}0.752 \\
{[1.370]}\end{array}$ & $\begin{array}{c}0.842 \\
{[1.411]}\end{array}$ & & & $\begin{array}{c}2.913 * * * \\
{[0.880]}\end{array}$ & $\begin{array}{c}2.674 * * * \\
{[0.895]}\end{array}$ \\
\hline $\ln$ (Assets) & & & $\begin{array}{c}-0.420 * * * \\
{[0.125]}\end{array}$ & $\begin{array}{c}-0.420 * * * \\
{[0.131]}\end{array}$ & & & $\begin{array}{c}-0.431 * * * \\
{[0.080]}\end{array}$ & $\begin{array}{c}-0.413 * * * \\
{[0.081]}\end{array}$ \\
\hline Capital/Assets & & & $\begin{array}{c}0.877 \\
{[1.242]}\end{array}$ & $\begin{array}{c}0.884 \\
{[1.252]}\end{array}$ & & & $\begin{array}{l}1.813 * * \\
{[0.818]}\end{array}$ & $\begin{array}{c}1.746 * * \\
{[0.814]}\end{array}$ \\
\hline Specie/Assets & & & $\begin{array}{c}-3.610 \\
{[3.255]}\end{array}$ & $\begin{array}{c}-3.754 \\
{[3.265]}\end{array}$ & & & $\begin{array}{c}-9.376^{* * *} \\
{[2.592]}\end{array}$ & $\begin{array}{c}-9.159 * * * \\
{[2.656]}\end{array}$ \\
\hline Loans/Assets & & & $\begin{array}{c}-0.417 \\
{[0.599]}\end{array}$ & $\begin{array}{c}-0.404 \\
{[0.607]}\end{array}$ & & & $\begin{array}{c}-1.442 * * * \\
{[0.475]}\end{array}$ & $\begin{array}{c}-1.483 * * * \\
{[0.481]}\end{array}$ \\
\hline Deposits/Assets & & & $\begin{array}{c}-5.477 * * * \\
{[2.086]}\end{array}$ & $\begin{array}{c}-5.484 * * * \\
{[2.057]}\end{array}$ & & & $\begin{array}{c}-1.905 \\
{[1.201]}\end{array}$ & $\begin{array}{c}-1.937 \\
{[1.211]}\end{array}$ \\
\hline Observations & 3,161 & 3,161 & 3,161 & 3,161 & 2,981 & 2,981 & 2,981 & 2,981 \\
\hline Pseudo R-squared & 0.218 & 0.219 & 0.238 & 0.238 & 0.139 & 0.143 & 0.178 & 0.179 \\
\hline
\end{tabular}

Notes: The model is a proportional-hazard partial likelihood model. The dependent variable is the whether the bank failed during the following five-year period. The model treats each five-year period a bank was open as a unique observation but links them under the individual bank. Fixed effects for state and each five-year period have been added to all specifications. Robust standard errors are listed below the coefficients in brackets. $*$ denotes significance at $10 \%$; ** at $5 \%$ level and $* * *$ at $1 \%$ level. 
Table 6: Effect of Transportation on Level of Bank Balance Sheets - Five Year Periods (1830-1860)

\begin{tabular}{|c|c|c|c|c|c|c|c|c|c|c|c|c|c|c|}
\hline \multirow[b]{2}{*}{ Ln(Bank Age) } & \multicolumn{2}{|c|}{ Ln(Assets) } & \multicolumn{2}{|c|}{ Capital/Assets } & \multicolumn{2}{|c|}{ Deposits/Assets } & \multicolumn{2}{|c|}{ Circulation/Assets } & \multicolumn{2}{|c|}{ Loans/Assets } & \multicolumn{2}{|c|}{ Bonds/Assets } & \multicolumn{2}{|c|}{ Specie/Assets } \\
\hline & $\begin{array}{c}0.027 * * * \\
{[0.002]}\end{array}$ & $\begin{array}{c}0.019 * * * \\
{[0.001]}\end{array}$ & $\begin{array}{c}0.001 \\
{[0.001]}\end{array}$ & $\begin{array}{c}-0.002 * * * \\
{[0.001]}\end{array}$ & $\begin{array}{c}0.001 * * * \\
{[0.001]}\end{array}$ & $\begin{array}{c}0.003 * * * \\
{[0.001]}\end{array}$ & $\begin{array}{c}-0.003 * * * \\
{[0.001]}\end{array}$ & $\begin{array}{c}-0.003 * * * \\
{[0.001]}\end{array}$ & $\begin{array}{c}0.001 * * * \\
{[0.001]}\end{array}$ & $\begin{array}{c}0.003 * * * \\
{[0.001]}\end{array}$ & $\begin{array}{c}-0.001 * * * \\
{[0.001]}\end{array}$ & $\begin{array}{l}-0.001 \\
{[0.001]}\end{array}$ & $\begin{array}{l}-0.001 \\
{[0.001]}\end{array}$ & $\begin{array}{c}-0.001 * * \\
{[0.001]}\end{array}$ \\
\hline $\begin{array}{l}\text { Free Bank } \\
\text { Dummy }\end{array}$ & $\begin{array}{c}-0.325 * * * \\
{[0.076]}\end{array}$ & & $\begin{array}{c}0.041 * * * \\
{[0.010]}\end{array}$ & & $\begin{array}{c}0.026 \\
{[0.016]}\end{array}$ & & $\begin{array}{c}-0.040 * * * * \\
{[0.012]}\end{array}$ & & $\begin{array}{c}-0.170 * * * \\
{[0.015]}\end{array}$ & & $\begin{array}{c}0.038 * * * \\
{[0.010]}\end{array}$ & & $\begin{array}{c}-0.022 * * * \\
{[0.003]}\end{array}$ & \\
\hline $\begin{array}{l}\text { Within } 10 \text { Miles } \\
\text { of Railroad }\end{array}$ & $\begin{array}{l}0.028 * \\
{[0.015]}\end{array}$ & $\begin{array}{c}0.004 \\
{[0.019]}\end{array}$ & $\begin{array}{c}-0.006 \\
{[0.004]}\end{array}$ & $\begin{array}{c}-0.008 \\
{[0.006]}\end{array}$ & $\begin{array}{c}-0.002 \\
{[0.003]}\end{array}$ & $\begin{array}{c}-0.012 * * * \\
{[0.004]}\end{array}$ & $\begin{array}{c}-0.016^{* * * *} \\
{[0.004]}\end{array}$ & $\begin{array}{c}0.005 \\
{[0.005]}\end{array}$ & $\begin{array}{c}0.018^{* * * *} \\
{[0.005]}\end{array}$ & $\begin{array}{l}0.014^{*} \\
{[0.008]}\end{array}$ & $\begin{array}{c}-0.003^{* *} \\
{[0.001]}\end{array}$ & $\begin{array}{c}-0.001 \\
{[0.001]}\end{array}$ & $\begin{array}{c}-0.004 * * * \\
{[0.001]}\end{array}$ & $\begin{array}{c}-0.006 * * * \\
{[0.002]}\end{array}$ \\
\hline $\begin{array}{l}\text { Within } 10 \text { Miles } \\
\text { of Canal }\end{array}$ & $\begin{array}{c}0.252^{* * *} \\
{[0.030]}\end{array}$ & $\begin{array}{c}0.026 \\
{[0.058]}\end{array}$ & $\begin{array}{c}0.005 \\
{[0.006]}\end{array}$ & $\begin{array}{c}-0.047 * * \\
{[0.021]}\end{array}$ & $\begin{array}{c}0.037 * * * \\
{[0.008]}\end{array}$ & $\begin{array}{l}0.036^{*} \\
{[0.019]}\end{array}$ & $\begin{array}{c}-0.061 * * * \\
{[0.006]}\end{array}$ & $\begin{array}{c}-0.025 \\
{[0.016]}\end{array}$ & $\begin{array}{c}0.027 * * * \\
{[0.007]}\end{array}$ & $\begin{array}{c}0.030 \\
{[0.026]}\end{array}$ & $\begin{array}{c}0.002 \\
{[0.004]}\end{array}$ & $\begin{array}{c}0.008 \\
{[0.009]}\end{array}$ & $\begin{array}{c}0.007 * * * \\
{[0.002]}\end{array}$ & $\begin{array}{c}0.018 * * * \\
{[0.007]}\end{array}$ \\
\hline $\begin{array}{l}\text { Within } 10 \text { Miles } \\
\text { of River }\end{array}$ & $\begin{array}{c}0.249 * * * \\
{[0.039]}\end{array}$ & & $\begin{array}{c}0.013 * * \\
{[0.006]}\end{array}$ & & $\begin{array}{c}0.025 * * * \\
{[0.008]}\end{array}$ & & $\begin{array}{c}-0.052^{* * * *} \\
{[0.007]}\end{array}$ & & $\begin{array}{c}0.040 * * * \\
{[0.008]}\end{array}$ & & $\begin{array}{l}-0.005 \\
{[0.007]}\end{array}$ & & $\begin{array}{c}0.001 \\
{[0.002]}\end{array}$ & \\
\hline $\begin{array}{l}\text { Within } 10 \text { Miles } \\
\text { of Great Lakes }\end{array}$ & $\begin{array}{c}0.045 \\
{[0.068]}\end{array}$ & & $\begin{array}{l}-0.008 \\
{[0.011]}\end{array}$ & & $\begin{array}{l}0.028^{*} \\
{[0.015]}\end{array}$ & & $\begin{array}{c}-0.064 * * * \\
{[0.013]}\end{array}$ & & $\begin{array}{c}0.040 * * \\
{[0.016]}\end{array}$ & & $\begin{array}{c}-0.030^{* *} \\
{[0.013]}\end{array}$ & & $\begin{array}{c}0.002 \\
{[0.004]}\end{array}$ & \\
\hline $\begin{array}{l}\text { Within } 10 \text { Miles } \\
\text { of Atl. Coast }\end{array}$ & $\begin{array}{c}0.565^{* * * *} \\
{[0.044]}\end{array}$ & & $\begin{array}{c}0.001 \\
{[0.006]}\end{array}$ & & $\begin{array}{c}0.083 * * * \\
{[0.008]}\end{array}$ & & $\begin{array}{c}-0.094 * * * * \\
{[0.007]}\end{array}$ & & $\begin{array}{c}0.005 \\
{[0.008]}\end{array}$ & & $\begin{array}{c}0.002 \\
{[0.003]}\end{array}$ & & $\begin{array}{c}0.015 * * * \\
{[0.002]}\end{array}$ & \\
\hline Fixed Effect & State & Bank & State & Bank & State & Bank & State & Bank & State & Bank & State & Bank & State & Bank \\
\hline Observations & 5,636 & 5,636 & 5,636 & 5,636 & 5,636 & 5,636 & 5,636 & 5,636 & 5,636 & 5,636 & 5,636 & 5,636 & 5,636 & 5,636 \\
\hline R-squared & 0.305 & 0.312 & 0.2183 & 0.223 & 0.1649 & 0.167 & 0.1926 & 0.202 & 0.0701 & 0.071 & 0.0135 & 0.014 & 0.0193 & 0.022 \\
\hline
\end{tabular}

Notes: Table presents the results of an OLS regression. The dependent variable is described in the column heading. Each observation is a bank-half decade. Dollar values are deflated to 1860 using Officer (2008). Fixed effects for each five-year period have been added to all specifications. Robust standard errors are listed below the coefficients in brackets. $*$ denotes significance at $10 \%$; $* *$ at $5 \%$ level and $* * *$ at $1 \%$ level. 
Figure 1: The Spread of Railroads and Banks, 1830-1860, by decade

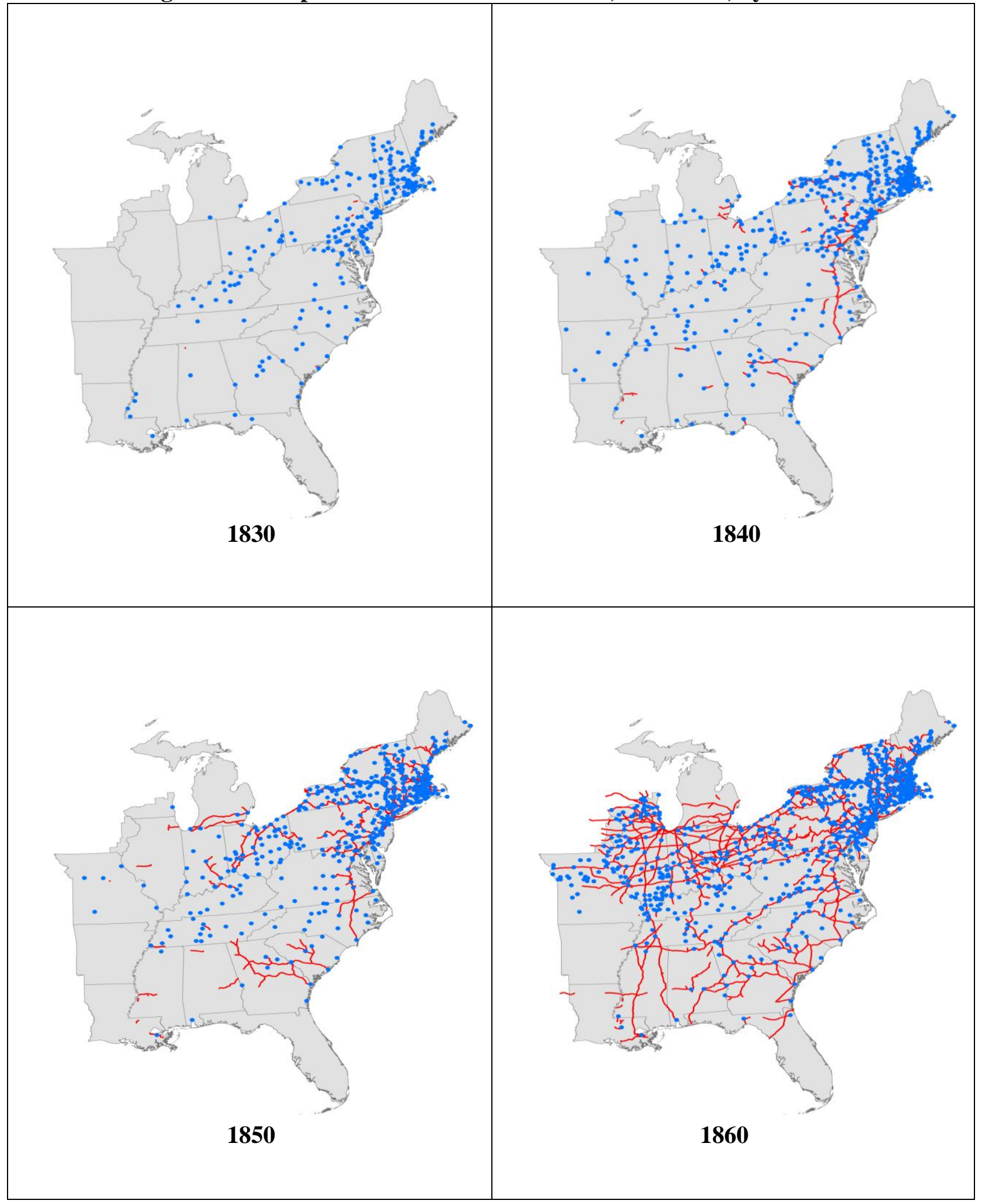

Notes: Figures display the location of railroads in banks in each year. 
Figure 2: Coefficient on Railroad Dummy Using Other Cutoffs

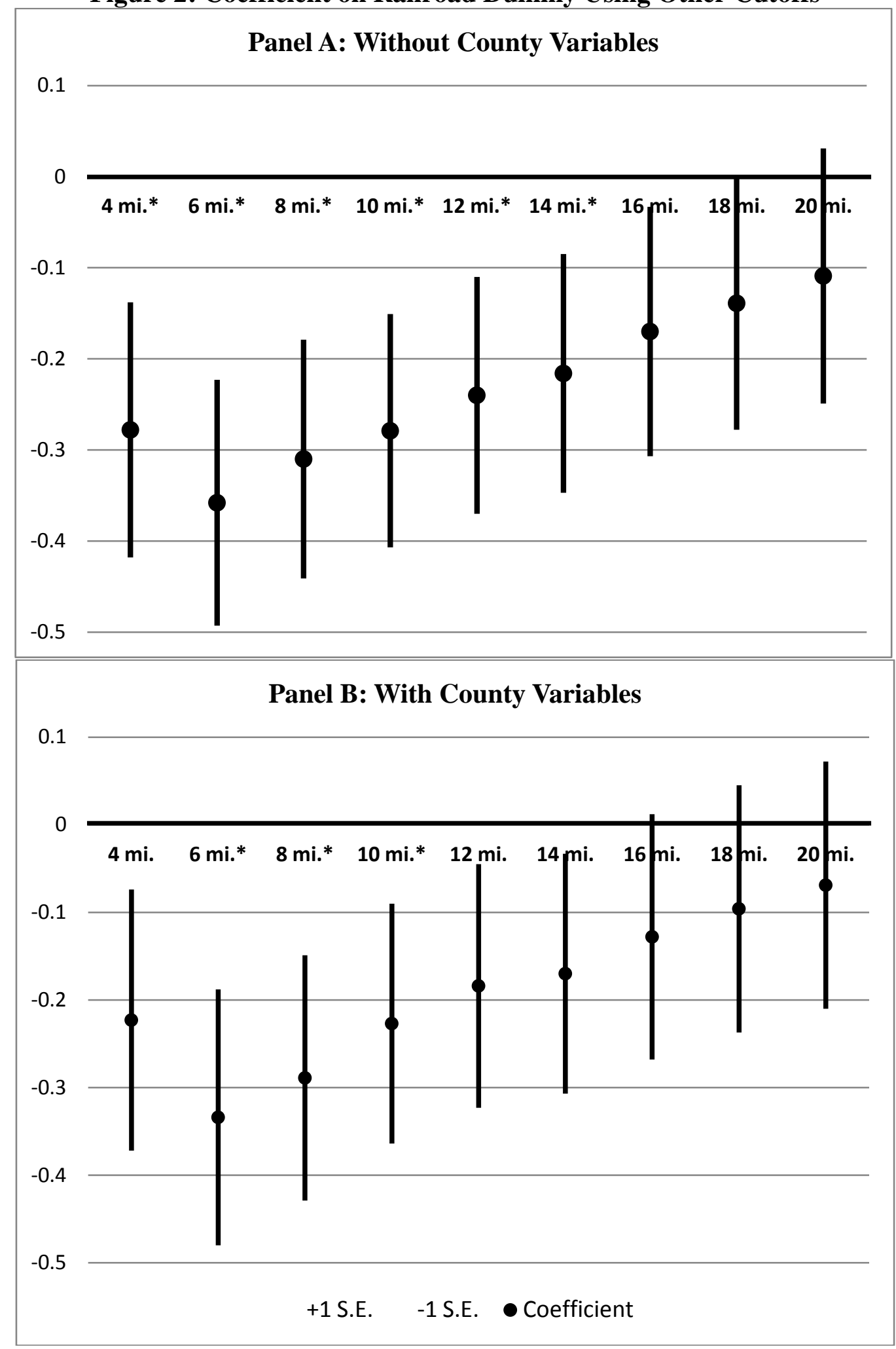

Notes: Figures present the coefficient on the railroad dummy for various mileage cutoffs. Each coefficient comes from an equation similar to those in columns (1) and (3) of Table 3. The stared mileage cutoffs denote coefficients that are statistically significant at the $10 \%$ level or greater. 